\title{
The Application of Comparative Psychology to Parapsychology: A Recommendation
}

\author{
Amanda Somers, Marlina D. Byrd, Brooklyne Curliss, Vanessa Lay, Ian T. Jones, \\ Charles I. Abramson
}

Oklahoma State University, Stillwater, USA

Correspondence to: Charles I. Abramson, charles.abramson@okstate.edu

Keywords: Comparative Psychology, Psi, Telepathy, Anpsi, OOM

Received: March 5, 2020 Accepted: June 2, $2020 \quad$ Published: June 5, 2020

Copyright (c) 2020 by author(s) and Scientific Research Publishing Inc.

This work is licensed under the Creative Commons Attribution International License (CC BY 4.0).

http://creativecommons.org/licenses/by/4.0/

\section{(c) (i) Open Access}

\section{ABSTRACT}

We propose that the comparative psychological principle of "levels" be used as a new research methodology to investigate psi in humans. Rather than investigate psi in animals, as is sometimes done, we propose to investigate psi in humans using animals as a receptor. Our approach is to start with simple organisms such as protozoans and progress to planarians and honey bees. The behavior of these organisms is well characterized and easily manipulated. Deviations from standard behavior patterns during an experiment on telekinesis can suggest psi effects. A major advantage of using invertebrates for psi research is that if a psi effect is found, the underlying mechanism of the effect can be analyzed using molecular and genetic tools. We provide suggestions on how telekinesis can be studied using this approach and suggest that Observation Oriented Modeling be used to analyze psi data.

\section{INTRODUCTION}

The purpose of this article is two-fold; first, we suggest that aspects of comparative psychology are applicable to psychic research. Comparative psychology has been defined as the application of the comparative method to problems of psychology and is arguably the first formal area of psychology [1,2]. Surprisingly, while there have been studies investigating psychical phenomena in animals [3], the methods and philosophy associated with comparative psychology is not applied to the detection of psychical phenomena in humans. Table 1 shows a listing of research into psi faculty in animals (anpsi) to demonstrate the history of how animals have historically been involved in psi research. The use of comparative psychology is unexplored in psychical research and has the potential to produce exciting and replicable research.

As a young graduate student, and then as a professor, the senior author (CIA) spent countless hours conditioning a variety of animals from invertebrates to vertebrates. In the course of these investigations the idea of whether it is possible to change an organism's choice or other aspects of its behavior by telepathy, telekinesis or other psychical means naturally presented itself. It is uncomplicated, for example, to 
Table 1. References for existing anpsi research.

\begin{tabular}{|c|c|c|}
\hline Species & Year & Citation \\
\hline Various & 1924 & $\begin{array}{l}\text { Bechterev, V. (1924). "Direct influence" of a person upon the behavior } \\
\text { of animals. Journal of Parapsychology, 13, 166-176. }\end{array}$ \\
\hline Equine & 1929 & $\begin{array}{l}\text { Rhine, J. B. and Rhine, L. E. (1929) An investigation of a "mind-reading" } \\
\text { horse. Journal of Abnormal and Social Psychology, 23, 449-466. }\end{array}$ \\
\hline Various & 1951 & $\begin{array}{l}\text { Rhine, J. B. (1951). The present outlook on the question of psi in animals. } \\
\text { Journal of Parapsychology, 15, 230-251. }\end{array}$ \\
\hline Feline & 1952 & $\begin{array}{l}\text { Osis, K. (1952). A test of the occurrence of a psi effect between man } \\
\text { and the cat. Journal of Parapsychology, 16, 233-256. }\end{array}$ \\
\hline Feline & 1953 & $\begin{array}{l}\text { Osis, K. and Foster, E. B. (1953) A test of ESP in cats. } \\
\text { Journal of Parapsychology, 17, 168-186. }\end{array}$ \\
\hline Mice & 1968 & $\begin{array}{l}\text { Duval, P., and Montredon, E. (1968). ESP experiments with mice. } \\
\text { Journal of Parapsychology, 32(3), 153-166. }\end{array}$ \\
\hline Various & 1970 & $\begin{array}{l}\text { Morris, R. L. (1970). Psi and animal behavior: a survey. Journal of the } \\
\text { American Society for Psychical Research, 64, 242-260. }\end{array}$ \\
\hline Various & 1971 & $\begin{array}{l}\text { Brown, B. (1971). ESP with Plants and Animals. New York: } \\
\text { Essandess Special Editions. }\end{array}$ \\
\hline Mice & 1972 & $\begin{array}{l}\text { Schouten, S. A. (1972). Psi in mice: positive reinforcement. } \\
\text { Journal of Parapsychology, 36, 261-282. }\end{array}$ \\
\hline Gerbils & 1974 & $\begin{array}{l}\text { Parker, A. (1974). ESP in gerbils using positive reinforcement. } \\
\text { Journal of Parapsychology, 38, 301-311. }\end{array}$ \\
\hline Rats & 1975 & $\begin{array}{l}\text { Terry, J. C. and Harris, S. A. (1975). Precognition in water-deprived rats. } \\
\text { Research in Parapsychology, 1974, } 81 .\end{array}$ \\
\hline Fish & 1976 & $\begin{array}{l}\text { Braud, W. G. (1976). Psychokinesis in aggressive and non aggressive fish } \\
\text { with mirror presentation feedback for hits: Some preliminary } \\
\text { experiments. Journal of Parapsychology, 40, 296-307 }\end{array}$ \\
\hline Various & 1977 & $\begin{array}{l}\text { Morris, R. L. (1977). Parapsychology, Biology, and ANPSI. } \\
\text { In B. B. Wolman (Eds.), Handbook of parapsychology(pp. 687-715). } \\
\text { Jefferson N.C.: McFarland \& Company, Inc. }\end{array}$ \\
\hline Various & 1987 & Bardens, D. (1987). Psychic Animals. London: Robert Hale \\
\hline Various & 1996 & $\begin{array}{l}\text { Armstrong, S. J. (1996). Souls in process: A theoretical inquiry into } \\
\text { animal psi. In M. Stoeber \& H. Meynell (Eds.), } \\
\text { Critical reflections on the paranormal (pp. 133-158). New York: SUNY }\end{array}$ \\
\hline Canine, Feline & 1998 & $\begin{array}{l}\text { Brown, D. J., and Sheldrake, R. (1998). Perceptive pets: A survey in northwest } \\
\text { California. Journal for the Society for Psychical Research, 62, 396-406. }\end{array}$ \\
\hline
\end{tabular}




\section{Continued}

\begin{tabular}{|c|c|c|}
\hline Various & 1998 & $\begin{array}{l}\text { Knight, E. E. (1998). Psychic pets: Supernatural true stories of } \\
\text { paranormal animals. School Library Journal, } 44(6), 172 .\end{array}$ \\
\hline Canine, Various & 1999 & $\begin{array}{l}\text { Sheldrake, R. (1999). Dogs that know when their owners are coming home: } \\
\text { And other unexplained powers of animals. New York, NY: Three Rivers Press. }\end{array}$ \\
\hline Canine & 1999 & $\begin{array}{l}\text { Maddox, J. (1999). Dogs, telepathy and quantum mechanics. Nature, } \\
\text { 401(6756), 849-850. }\end{array}$ \\
\hline Canine & 2001 & $\begin{array}{l}\text { Taylor, R. (2001). Dogs that know when their owners are coming home: } \\
\text { And other unexplained powers of animals. } \\
\text { The Journal of Parapsychology, 65(1), 90-96. }\end{array}$ \\
\hline Various & 2002 & $\begin{array}{l}\text { Brunke, D. B. (2002). Animal voices. } \\
\text { telepathic communication in the web of life. Rochester: Bear \& Company. }\end{array}$ \\
\hline Various & 2002 & $\begin{array}{l}\text { Nickell, J. (2002, Nov). Psychic pets and pet psychics. } \\
\text { The Skeptical Inquirer, 26, 12-15+. }\end{array}$ \\
\hline Various & 2002 & $\begin{array}{l}\text { Lohr, G. A. (2002). Psychic pets network. } \\
\text { Washington Business Journal, 20(47), } 3 .\end{array}$ \\
\hline Various & 2003 & Schul, B. (2003). The psychic power of animals. New York: An Book. \\
\hline Canine, Feline & 2003 & Sheldrake, R. (2003, Dec 27). Animal magic. The Spectator, 293, 25. \\
\hline Avian & 2003 & $\begin{array}{l}\text { Sheldrake, R. \& Morgana, A. (2003). Testing a language-using parrot for } \\
\text { telepathy. Journal of Scientific Exploration, 17(4), 601-616. }\end{array}$ \\
\hline Various & 2009 & $\begin{array}{l}\text { Dutton, D., and Williams, C. (2009). Clever beasts andfaithful pets: a critical } \\
\text { review of animal psi research. The Journal of Parapsychology, 73, 43-70. }\end{array}$ \\
\hline Various & 2011 & $\begin{array}{l}\text { Erickson, D. L. (2011). Intuition, Telepathy, and Interspecies } \\
\text { Communication: A Multidisciplinary Perspective. Neuro Quantology, 9(1). }\end{array}$ \\
\hline Various & 2012 & $\begin{array}{l}\text { Knight, E. E. (1998). Psychic pets: Supernatural true stories of paranormal } \\
\text { animals. School Library Journal, 44(6), } 172 .\end{array}$ \\
\hline Canine & 2014 & $\begin{array}{l}\text { Kirk R. G. (2014). In dogs we trust? Intersubjectivity, response-able } \\
\text { relations, and the making of mine detector dogs. } \\
\text { Journal of the history of the behavioral sciences, 50(1), 1-36. }\end{array}$ \\
\hline Canine & 2016 & $\begin{array}{l}\text { Erickson, D. L., Fisher, D., Woelk, B., Buckner, W., \& Ashley, C. (2016). } \\
\text { A Mixed Methods Study of Telepathic Interspecies Communication } \\
\text { with Therapeutic Riding Horses and Their Recovering } \\
\text { Wounded Veteran Partners. Neuro Quantology, 14(2). }\end{array}$ \\
\hline Various & 2018 & $\begin{array}{l}\text { Duggan, M. (2018). “Animals in Psi Research". Psi Encyclopedia. London: } \\
\text { The Society for Psychical Research. }\end{array}$ \\
\hline
\end{tabular}


train a honey bee to choose between two targets differing in color, odor and/or position [4]. The question arises whether it is possible to change the bee's choice or other behavior, using psychic phenomena.

The second purpose of this article is to suggest that Observation Oriented Modeling (OOM) be used to analyze psychical data. OOM has a number of advantages over traditional statistical tests. These advantages include: encouraging researchers to create integrated models to explain data patterns rather than estimate parameters as in standard statistical methods, the absence of aggregate statistics as means, variances, and correlations, and perhaps most importantly, $P$-values are eliminated. We have successfully used OOM for several of our honey bee papers [5-7] and advocate its use in comparative studies [8].

Experimental parapsychology peaked in the 1960s and 1970s as investigators sought to establish psi's position in biological and evolutionary frameworks [9]. Rhine himself suggested animal psi, coined anpsi, has potential to lead to an understanding of the evolutionary foundation of psi. The latter half of this timespan focused on developing experimental procedures and automating systems [9]. This endeavor has continued. In his 1986 article Ray Hyman [10] suggested that the new generation of parapsychologists were working toward higher standards but that the best systematic approaches were still insufficient and would fail to stand up to the scrutiny of the scientific community. A dominant challenge facing psi researchers is the prevalence of case studies that offer very small sample sizes and are often unable to be reproduced.

There needs to be a shift from subjective evidence to objective evidence. It has been suggested that parapsychologists need to obtain replication rates of $80 \%$ or better to meet the expectations of appropriated scientific research [11]. Replication in psi suffers rates of $20 \%$ - 33\% but has remained constant over decades. The field of psychology has been under similar scrutiny in recent years [12]. The types of comparative studies we are promoting mitigate the negative effects of the replication crisis by providing experiments that are easily replicated worldwide with easily accessible materials and with many species to provide robustness to findings.

\section{THE USE OF LEVELS TO DETECT TELEKINESIS}

One of the basic tenets of comparative psychology is the idea of "levels". While various comparative theorists may disagree on what should, or should not be, included in a particular level, it is generally agreed that organisms lower on the phyletic scale do not possess the range and complexity of behaviors of animals higher up on the scale [13-16]. This levels approach comes directly from the philosophical speculation of Aristotle and St. Thomas Aquinas [17].

\section{SUGGESTIONS AND GENERAL STRATEGY: TELEKINESIS}

The idea of "psychological" levels suggests a general strategy for the exploration of psi phenomena in humans. We illustrate this approach by focusing on telekinesis, although other psychic phenomena can be explored using the same principles. As a general strategy, we recommend that researchers start with unicellular organisms such as protozoans and work their way up the complexity scale to planarians and honey bees.

The rationale for selecting these organisms are three-fold. First, they serve as model organisms with well characterized and replicable behavior, second, there are many molecular techniques that can be used to study various aspects of underlying mechanisms and third, the authors have extensive experience with the organisms. Experience with the organisms is necessary in the design of experiments. We also like to note that they are relatively inexpensive and easy to procure and maintain compared to vertebrates. Planarians and protozoans can be obtained from a number of biological supply houses such as Carolina Biological Supply (www.carolina.com) or Ward's Science (www.wardsci.com). Honey bees can be obtained from local beekeepers or from bee supply companies such as Mann Lake (www.mannlakeltd.com) and Dadant (www.dadant.com).

It is also important to note that researchers may use other invertebrates such as Aplysia and Drosophila (fruit flies). Fruit flies are particularly useful because of the possibility to conduct genetic experi- 
ments. One can imagine that if human telekinesis influences fruit fly behavior, studies can be conducted that may actually reveal what genes are influenced by telekinesis with the possibility of producing a line of flies that are sensitive to telekinetic effects.

Information about specific invertebrates is readily available from the internet and from general invertebrate biology books [18]. There are more than 40,000 protozoan species ranging in size from $1 \mu \mathrm{m}$ to 10 $\mathrm{mm}$. Protozoans are distinctive in that their organismic activities, such as respiration, are performed within a single cell and they have a surprising range of behavior including predation and motility.

Three major categories of protozoa are recognized. Flagellates are the smallest protozoans and move through their environment by the use of flagella. Well studied examples are Stentor roeselli and $S$. coeruleus. Amoebae move by protoplasmic flow. Amoeba proteus, Chaos carolinense, and Naegleria fowleri are examples of well-studied species. Ciliates move by beating cilia that cover the surface of the cell with arguably the most popular species Paramecium caudatum and $P$. Aurelia.

Planarians (also known as flatworms) belong to the phylum Platyhelminthes. Planarians range in size from 0.5 to $5 \mathrm{~cm}$ and are predominately found in aquatic environments. The most familiar species are Dugesia tigrina, D. dorotocephala, and Phagocata gracilis. Planarians are well studied and have an impressive range of behavior. Many techniques are available to study their behavior and molecular techniques to explore the underlying mechanisms exist. Moreover, the appearance of a brain, bilateral symmetry, polarized neurons, and definitive anterior and posterior ends-with the anterior end containing a head, "eyes," and other sense organs first occur in planarians.

Honey bees are in the phylum Arthropoda. There are about 4000 species of bees placed into nine families. Some of the more common bees are bumble bees, sweat bees, carpenter bees, and perhaps the most well-known social insect-the honey bee. The behavior of the honey bee is complex and there are many behavioral and molecular techniques to examine their behavior.

\section{Suggested Experiments}

The strategy we advocate is to find a behavior that is well characterized and replicable. To test telekinesis, for example, the prospective human participant attempts to change the behavior of the organism. Habituation is easily observed in Stentor roeselli and $S$. coeruleus [4]. The question of interest is whether the human participant can influence the learning of the single cell organism. Standard behavioral controls are implemented to guard against false positives.

If an effect is found, studies could be extended to include any behavior the researcher is interested in such as feeding or motility. Moreover, molecular tools can be used to gain insight into the underlying mechanisms. To our knowledge, molecular tools have yet to be applied to psi research.

One would expect that if telekinesis were an actual effect (i.e., replicable) it should influence the behavior of a single cell. Equally exciting is that if an effect is found not only can molecular tools be used but "filters" can be placed in between the human participant and the single-celled organism in an attempt to block the effect. This would provide the researcher with some physical property, such as wavelength/size, associated with telekinesis.

The same research strategy could be used with planarians. Planarians have even more interesting behavior including the ability to regenerate. Moreover, planarians are a model organism for many areas of science including learning, development, neural networks, gene expression, and regeneration [19]. Planarians represent a significant advance over single-celled organisms. There are many experiments in the literature on planarian behavior that can be used to study telekinesis. Just as fruit flies can be used to understand the genetics of telekinesis, the remarkable regenerative powers of planarians can provide exciting data on the transfer of the effect to regenerates-i.e. offspring.

An even more advanced organism is the honey bee. Honey bees represent a significant progress over single-celled organisms and planarians. Honey bees are also a model organism for many aspects of behavior and molecular analysis. Compared to protozoans and planarians, honey bees have a well-known social structure and are one of the more popular animals used in research [20].

When using protozoans, planarians and honey bees our suggestion is to first study changes in baseline movements-kineses, taxes, and compass reactions [21]. The question here is whether the human par- 
ticipant can influence baseline movements. Honey bees can be placed in a shuttle box and their movement between the two compartments easily manipulated by simply turning lights on and off. If the honey bee is in "Compartment $A$ " all one needs to do is turn the light off in " $A$ " and turn on a light on in Compartment "B." The bee will move toward the light. Planarians also have similar reactions to light.

A second suggestion is to study choice behavior. Planarians and honey bees have been examined in many choice situations using a variety of mazes. Interestingly, although not always replicable, data suggests that protozoans can also be tested in choice situations $[22,23]$. As mentioned earlier, honey bees can easily be studied in choice situations using either the free-flying technique where bees distinguished targets by color, order, and/or position, the shuttle box technique, or the proboscis extension response technique where restrained honey bees receive pairings of a conditioned stimulus (CS) and unconditioned stimulus (US). After several CS-US pairings, the bee extends its proboscis to the CS [24].

A third suggestion is to determine whether the human participant can influence the timing behavior of honey bees. Bees are trained to visit flowers at particular times of the day. The question of interest is whether telekinesis can influence timing behavior [5].

\section{OBSERVATION ORIENTED MODELING}

When analyzing psi data, we suggest utilizing Observation Oriented Modeling [25]. OOM is a data analytic approach that eschews aggregate statistics, such as means, variances, correlations, and effect sizes (e.g., $d, r$, or $\eta^{2}$ ). Instead, OOM relies on identifying and interpreting patterns of observations at the level of the individual in a given study. Moreover, OOM encourages researchers to create models that outline the causal structures and processes underlying observed phenomena [26]. These models, referred to as Integrated Models, are person-centered and distinct from variable-centered path and SEM models.

Philosophical positivism is a viewpoint that has largely been abandoned by philosophers due to several important shortcomings [27]. In contrast to philosophical positivism, moderate realism posits that things (e.g., people, animals, objects) have natures and that these natures can be known [28, 29]. Integrated Models are rooted in philosophical realism and incorporate Aristotle's four causes (formal, material, efficient, and final), as discussed in Physics (Book II, Chapter 3) and Metaphysics (Books I - VII) [28, $30,31]$. Unlike variable based models, Integrated Models are typically drawn prior to data analysis and outline the formal, material, efficient, or final causes that explain a given phenomenon [25, 32-36]. To interpret the success or failure (i.e., model fit) of an Integrated Model, OOM incorporates a Percent Correct Classification (PCC) index. The PCC can be interpreted as a person-centered effect size that allows researchers and laypersons alike to answer the question, "how many individuals in my study responded or behaved consistent with theoretical expectations [37]."

Previous research utilizing traditional significance testing, rooted in philosophical positivism, has demonstrated evidence in support of psi phenomena [38, 39]. Specifically, it was successfully demonstrated that participants' prescient responses to arbitrary stimuli was, on average, greater than what might be expected by chance [39]. In addition to the methodological and statistical criticisms of these studies [40, 41], it must also be pointed out that Bem and his colleagues did not provide a causal model to explain their effects. From the standpoint of philosophical realism, scientific knowledge is causal knowledge of the natural world. We therefore strongly encourage psi researchers to create Integrated Models that explicate the causal nature of psi phenomenon and then test these models at the level of the individual, not at the level of the aggregate.

\section{DISCUSSION}

We believe that the use of the comparative psychological concept of "levels" can be profitably used in psychical research. Our suggestion of using invertebrates of varying complexity to study human psi is both novel and potentially fruitful. We are confident that our suggestion of using invertebrates to tell us something about psi in humans rather than studying psi in animals is also novel.

The use of invertebrates for psychical research has much to recommend it. First, the behavior of pro- 
tozoans, planarians, and honey bees are well characterized with the underlying mechanisms of many of their behaviors known. Second, invertebrates exhibit an almost bewildering array of behavior, many of which can be used in psi research. Third, the use of invertebrates can supply replicable data in case studies. Case studies are often problematic in psi research because of small sample sizes. If a case study includes replicable changes in an invertebrate behavior the case is made much stronger even with a sample size of one. Fourth, many automated apparatus are available to study invertebrate behavior thereby increasing replication [25]. These apparatuses can be connected to a microcontroller for behavioral research that is both versatile and low cost $[42,43]$, again increasing the ability to replicate findings.

We also advocate the use of OOM to analyze psychical data. As discussed earlier, OOM has many advantages over traditional statistics. OOM is not only easy to use, it is assumption free, eliminates the need for $P$-values, and tests the integrated model created by the researcher. Researchers working on psychic phenomena would be well served to consider OOM to analyze their data. For those researchers hesitant about using OOM we suggest analyzing data by both methods.

We would also like to note that that psychic phenomena captures the imagination of students. Using invertebrates to study psychic phenomena can serve as undergraduate research projects thereby helping to create a new generation of students interested in researching psychic phenomena.

If you would like assistance incorporating comparative methods into your experimental design, please contact the senior author. Our laboratory is very open to collaboration. Correspondence regarding this article should be addressed to Charles Abramson, Oklahoma State University Laboratory of Comparative Psychology and Behavioral Biology (Charles.abramson@okstate.edu).

\section{ACKNOWLEDGEMENTS}

The authors would like to thank Dr. James Grice for his discussions on using OOM for anpsi research.

\section{CONFLICTS OF INTEREST}

All authors state that there are no competing interests regarding this work.

\section{REFERENCES}

1. Abramson, C.I. (2015) A Crisis in Comparative Psychology: Where Have All the Undergraduates Gone? Frontiers in Psychology, 6, 1500. https://doi.org/10.3389/fpsyg.2015.01500

2. Abramson, C.I. (2018) Let Us Bring Comparative Psychology Back. International Journal of Comparative Psychology, 31, 1-15. https://escholarship.org/uc/item/81j662cd

3. Morris, R.L. (1977) Parapsychology, Biology, and ANPSI. In: Wolman, B.B., Ed., Handbook of Parapsychology, McFarland \& Company, Inc., Jefferson, 687-715.

4. Abramson, C.I. (1990) Invertebrate Learning: A Laboratory Manual and Source Book. American Psychological Association, Washington DC. https://doi.org/10.1037/10078-000

5. Craig, D.P.A. and Abramson, C.I. (2015) A Need for Individual Data Analysis for Assessment of Temporal Control: Invertebrate Fixed-Interval Performance. International Journal of Comparative Psychology, 28, 1-39. https://doi.org/10.1016/j.beproc.2015.08.006

6. Dinges, C.W., et al. (2013) Aversive Conditioning in Honey Bees (Apis mellifera anatolica): A Comparison of Drones and Workers. Journal of Experimental Biology, 216, 4124-4134. https://doi.org/10.1242/jeb.090100

7. Dinges, C.W., Varnon, C.A., Cota, L.D., Slykerman, S. and Abramson, C.I. (2017) Studies of Learned Helplessness in Honey Bees (Apis melliferaligustica). Journal of Experimental Psychology: Animal Learning and Cognition, 43, 147-158. https://doi.org/10.1037/xan0000133

8. Craig, D.P.A. and Abramson, C.I. (2018) Ordinal Pattern Analysis in Comparative Psychology-A Flexible Al- 
ternative to Null Hypothesis Significance Testing Using an Observation Oriented Modeling Paradigm. International Journal of Comparative Psychology, 31, 1-20.

9. Dutton, D. and Williams, C. (2009) Clever Beasts and Faithful Pets: A Critical Review of Animal Psi Research. Journal of Parapsychology, 73, 43-70.

10. Hyman, R. (1986) Parapsychological Research: A Tutorial Review and Critical Appraisal. Proceedings of the IEEE, 74, 823-849. https://doi.org/10.1109/PROC.1986.13557

11. Carter, C. (2012) Science and the Psychic Phenomena: The Fall of the House of Skeptics. Inner Traditions, Rochester.

12. Open Science Collaboration (2015) Estimating the Reproducibility of Psychological Science. Science, 349, aac4716. https://doi.org/10.1126/science.aac4716

13. Pisula, W. (1998) Integrative Levels in Comparative Psychology-The Example of Exploratory Behavior. European Psychologist, 3, 62-69. https://doi.org/10.1027/1016-9040.3.1.62

14. Razran, G. (1971) Mind in Evolution: An East-West Synthesis of Learned Behavior and Cognition. Houghton Mifflin, Boston.

15. Schneirla, T.C. (1949) Levels in the Psychological Capacities of Animals. In: Sellars, R.W., McGill, V.J. and Farber, M., Eds., Philosophy for the Future, Macmillan, New York, 243-286.

16. Schneirla, T.C. (1953) The Concept of Levels in the Study of Social Phenomena. In: Sherif, M. and Sherif, C., Eds., Groups in Harmony and Tension, Harper, New York, 54-75.

17. Brown, E.A. and Abramson, C.I. (2019) Aristotelean-Thomistic Approach to Comparative Psychology. International Journal of Comparative Psychology, 32, 1-10.

18. Penchenik, J.A. (2015) Biology of the Invertebrates. McGraw-Hill, New York.

19. Raffa, R.B. and Rawls, S.M. (2008) Planaria: A Model for Drug Action and Abuse. Landes Bioscience, Austin. https://doi.org/10.1201/9781498713597

20. Tautz, J. (2009) The Buzz about Bees: Biology of a Superorganism. Springer, Berlin. https://doi.org/10.1007/978-3-540-78729-7

21. Fraenkel, G.S. and Gunn, D.L. (1961) The Orientation of Animals: Kineses, Taxes and Compass Reactions. Dover Publications, Inc., New York. (Originally Published 1940)

22. Alipour, A., Dorovash, M., Yaganeh, Y. and Hatam, G. (2008) Paramecium Learning: New Insights and Modifications. Journal of Protozoology Research, 28, 22-32.

23. Boisseau, R.P., Vogel, D. and Dussutour, A. (2016) Habituation in Non-Neural Organisms: Evidence from Slime Moulds. Proceedings of the Royal Society B: Biological Sciences, 283, Article ID: 20160446. https://doi.org/10.1098/rspb.2016.0446

24. Abramson, C.I. (1994) A Primer of Invertebrate Learning: The Behavioral Perspective. American Psychological Association, Washington DC. https://doi.org/10.1037/10150-000

25. Grice, J.W. (2011) Observation Oriented Modeling: Analysis of Cause in the Behavioral Sciences. Academic Press, New York.

26. Grice, J.W. (2014) Observation Oriented Modeling: Preparing Students for Research in the $21^{\text {st }}$ Century. Innovative Teaching, 3, 1-27. https://doi.org/10.2466/05.08.IT.3.3

27. Costa, R.E. and Shimp, C.P. (2011) Methods Courses and Texts in Psychology: "Textbook Science" and "Tourist Brochures”. Journal of Theoretical and Philosophical Psychology, 31, 25-43. https://doi.org/10.1037/a0021575

28. Wallace, W.A. (1996) The Modeling of Nature. Catholic University Press, Washington DC.

29. Dougherty, J. (2013) The Nature of Scientific Explanation. Catholic University of America Press, Washington 
DC.

30. Rychlak, J. (1988) The Psychology of Rigorous Humanism. 2nd Edition, New York University Press, New York.

31. Falcon, A. (2012) Aristotle on Causality. In: Zalta, E.N., Ed., The Stanford Encyclopedia of Philosophy, 2012 Edition. http://plato.stanford.edu/archives/win2012/entries/aristotle-causality

32. Grice, J.W., Barrett, P.T., Schlimgen, L.A. and Abramson, C.I. (2012) Toward a Brighter Future for Psychology as an Observation Oriented Science. Behavioral Sciences, 2, 1-22. https://doi.org/10.3390/bs2010001

33. Grice, J.W. (2015) From Means and Variances to Persons and Patterns. Frontiers in Psychology, 6. https://doi.org/10.3389/fpsyg.2015.01007

34. Grice, J.W., Cohn, A., Ramsey, R.R. and Chaney, J.M. (2015) On Muddled Reasoning and Mediation Modeling. Basic and Applied Social Psychology, 37, 214-225. https://doi.org/10.1080/01973533.2015.1049350

35. Grice, J.W., Yepez, M., Wilson, N.L. and Shoda, Y. (2017) Observation-Oriented Modeling: Going beyond "Is It All a Matter of Chance"? Educational and Psychological Measurement, 77, 855-867. https://doi.org/10.1177/0013164416667985

36. Grice, J.W., et al. (2017) Four Bad Habits of Modern Psychologists. Behavioral Sciences, 7, 53. https://doi.org/10.3390/bs7030053

37. Grice, J.W., Medellin, E., Jones, I.T., Horvath, S., McDaniel, H., O’lansen, C. and Baker, M. (Unpublished) Persons as Effect Sizes. Advances in Methods and Practices in Psychological Science.

38. Bem, D.J. (2011) Feeling the Future: Experimental Evidence for Anomalous Retroactive Influences on Cognition and Affect. Journal of Personality and Social Psychology, 100, 407-425. https://doi.org/10.1037/a0021524

39. Bem, D.J., Utts, J. and Johnson, W.O. (2011) Must Psychologists Change the Way They Analyze Their Data? Journal of Personality and Social Psychology, 101, 716-719. https://doi.org/10.1037/a0024777

40. Wagenmakers, E., Wetzels, R., Borsboom, D. and van der Maas, H.L.J. (2011) Why Psychologists Must Change the Way They Analyze Their Data: The Case of Psi: Comment on Bem (2011). Journal of Personality and Social Psychology, 100, 426-432. https://doi.org/10.1037/a0022790

41. Alcock, J. (2011) Back from the Future: Parapsychology and the Bem Affair. Skeptical Inquirer, 35, 31-39. https://skepticalinquirer.org/exclusive/back-from-the-future

42. Varnon, C.A. and Abramson, C.I. (2013) The Propeller Experiment Controller: Low-Cost Automation for Classroom Experiments in Learning and Behavior. Innovative Teaching, 2, 1-18. https://doi.org/10.2466/07.08.IT.2.2

43. Varnon, C.A. and Abramson, C.I. (2018) The Propeller Experiment Controller. Journal of Mind and Behavior, 39, 1-153. 